\title{
The Philosophy behind USA, United Kingdom, Germany, France Lion's Share in Nobel Prizes: Creative Ideas for Other Countries
}

\author{
M. B. Dastagiri \\ Principal Scientist \\ ICAR-National Academy of Agricultural Research Management \\ Rajendranagar, Hyderabad-500030. India. \\ P. V. Naga Sindhuja \\ Young Professional \\ ICAR-NAARM, Rajendranagar \\ Hyderabad-500030. \\ Manju Yadav \\ Young Professional \\ ICAR-NAARM, Rajendranagar, Hyderabad-500030
}

Nobel Prize is the extreme prestigious award in an intellectual space. The new revolutionary inventions awarded will fuel other researchers to build many achievements in a Universe. The present paper estimated shares, percentages, significant contribution and analyses global, continental, country and subject wise Nobel Prize laureate's inventions in general, USA, UK, Germany and France in particular since most of the Nobel laureates were from these nations. The study would help to galaxy of future inventors. The study is based on the frame work of explorative, meta-analysis \& Delphi survey methods of great Nobel Prize awardees. The study found that 91 per cent of Nobel Prizes had been given to North America and Europe laureates and more or less same percent the two continents received equally. Only $1 \%$ of Nobel Prize awarded to Australia, Africa and South America laureates. USA laureates took the dominant place in economic sciences which accounted 79.76\%. The researchers of USA, UK, Germany and France get more Nobel Prizes in all categories across the world. Number of USA Nobel laureates in physics, chemistry, medicine, peace and economics were more than UK, Germany and France. However, France population has a relatively high IQ in literature when compared to USA, UK and Germany. The study found that the Nobel prizes awardees are Europe and USA centric rather than global centric. This may be due to more creative minds, more $R \& D$ investments and industrialization. Most of the foreign intellectuals work for USA, but these countries were not encouraged innovative intellectuals and no financial support from governments especially in research areas. The inventions from all categories are very helpful in humanity through several ways such as future progress of people, technological advances in future, environmental safety, good health, providing safe drinking water facilities, food security, human culture, traditions, values, behavior, reality, tragedy, truth, love, inspiration, true-happiness, business trade and economic growth of the nations. The study suggest that the Royal Swedish academy and UNO-UNESCO have to bring awareness programs in selection procedures in Asia, Africa, Latin American countries. Government of all nations should encourage intellectuals and support financially to expose new thoughts for outside world. Nobel Prize selection committee must select winners from other than six disciplines.

Keywords: Nobel laureates, USA, Europe, Explorative analysis. Policy advocacy

\section{Introduction:}

Over the years, we are gradually losing a set of morals, mainly humanistic ones for which the Nobel Prizes are one of our last bastions. Nobel Prize is the extreme prestigious award awarded not only of excellence, but also of honesty, passion, and pledge to morals that motivates both professionals and nonprofessionals in the intellectual space $^{1}$. The achievement must generate "a substantial impact for the sphere, a richness of outcomes and have an almost breakthrough importance"2. The essence of scientific glory, Nobel Prize is the heritage of Alfred Nobel who is an inventor of dynamite known as "the merchant of death" because the role of his dealership led to kill more people faster than ever before. He created the eponymous prizes "for the greatest benefit of mankind" to rehabilitate his name ${ }^{3}$. He declared his last will that his assets counting 31 million SEK should be converted as fund and the interest comes from that should be distributed as Nobel Prize to those people who helps to improve society through science, knowledge and humanism ${ }^{4}$. The four institutions namely, The Royal Swedish Academy of Sciences, Sveriges Riksbank, The Swedish Academy, Karolinska Institute and The Norwegian Nobel Committee awards the Nobel Prize in physics \& chemistry, economic sciences, literature, physiology or medicine and peace respectively created the Nobel foundation based on the Alfred Nobel's will in $1900^{5}$. The Nobel Prize is currently SEK 9 Million worth in each category. 
For each Nobel Prize, there can be up to three recipients who share the prize amount equally. Nobel winners must be alive, and more than three people cannot share a Nobel ${ }^{6}$. The Nobel committee considers diversity in gender and nationality for the 2019 prizes for the first time ${ }^{7}$. Mainly in physics \& chemistry, it does not need extraordinary youth to win prize, the chances decrease markedly in mid-life period and fall off quickly after 50 years age ${ }^{8}$. Women awarded the Nobel Prize and Prize in Economic Sciences 54 times in between 1901 and 2019. They are a ridiculous and old-fashioned way of recognizing scientists every year, when Nobel Prizes awarded in physics, chemistry, and physiology or medicine, critics ${ }^{10}$. The prizes do not have the impact, but instead the discoveries that led to the prizes. The new revolutionary inventions awarded will fuel other researchers to build many achievements in a Universe ${ }^{11}$.

\section{Methodology}

The entire study has made based on secondary data sources mainly from the website of Nobel Prize Organization (www.nobelprize.org). The study period was from 1901 to 2019. Nobel Prize laureates of all categories have collected data for six continents namely, Africa, Asia, Australia, Europe, North America and South America. The present paper estimated shares and percentages and analyses global, continental, country and subject wise Nobel Prize laureate's inventions in general, USA,UK, Germany and France in particular since most of the Nobel laureates were from these nations. Decade wise significant contributions of physics, chemistry, medicine, literature, peace and economic sciences were analyzed. The current study was based on the framework of explorative, metaanalysis and Delphi survey methods of great Nobel Prize awardees.

Philosophy of Puzzle:

Creative minds contributed to the development of universe and humanity. Oxford Dictionary defined "Philosophy" as "love of wisdom or know-how of fundamental truth (www.math). The new revolutionary inventions awarded will fuel other researchers to build many achievements in a Universe in future. The essence of scientific glory, Nobel Prize is the heritage of Alfred Nobel who is an inventor of dynamite known as "the merchant of death" because the role of his dealership led to kill more people faster than ever before. Alfred created the eponymous prizes "for the greatest benefit of mankind". However, a significant degree of US prominence in global science can attribute to its sheer size, finds an analysis of Nobel laureates in the natural sciences relative to population. The study of four nations, the US, Germany, France and the United Kingdom, published in Royal Society Open Science, covers the entire period since the Swedish Academy first awarded the prize in 1901.The researchers of USA, UK, Germany and France get more Nobel prizes. Are they more creative or more R\& D or more enabling environment need to be examined?

The present paper analyses global, continental, country and subject wise analysis of Nobel prize laureate's inventions, theories, evidences, insights, knowledge, ideas and rationales of great persons that would help to galaxy of future inventors. The specific objectives of the paper are:

1.To estimate the share of continent-wise, country-wise and subject wise Nobel Prizes awarded in the globe.

2. To analyze country wise Nobel laureates' trends awarded in different categories of prizes across continents.

3. To find out the decade wise significant contributions of Nobel Prize laureates.

4. To suggest strategies and policies for future Nobel Prizes.

\section{Results:}

\section{Continent-wise Share of Nobel Prize Laureates in Six Different Categories (1901 to2019):}

The Nobel Prize has awarded to 27 organizations and 923 laureates (total 950) during the period from 1901 to 2019. Out of them, 213 are laureates in physics, 184 are laureates in chemistry, 219 are laureates in medicine, 116 are laureates in literature, 107 are laureates in peace and 84 are laureates in Economic Sciences.

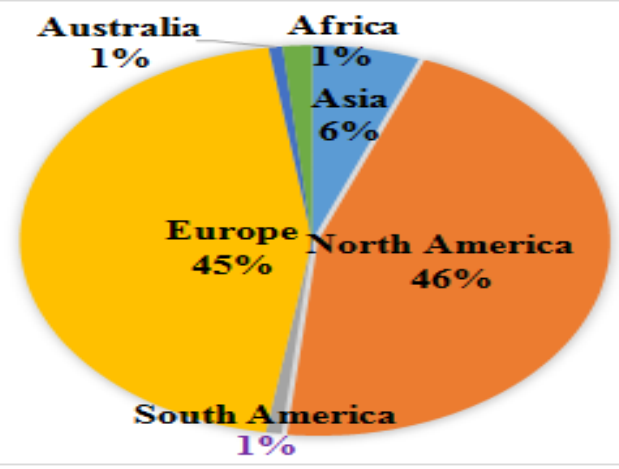

$$
\begin{aligned}
& \text { - Asia } \\
& \text { - North America } \\
& \text { - South America } \\
& \text { Europe } \\
& \text { - Australia } \\
& \text { - Africa }
\end{aligned}
$$

Fig. 1 Percentage share of Nobel Prize Laureates in Six Different Categories across the continents 
91 per cent of Nobel Prizes had been given to North America and Europe laureates and more or less same percent these two continents received equally. Only $1 \%$ of Nobel Prize awarded to Australia, Africa and South America laureates (Fig. 1).

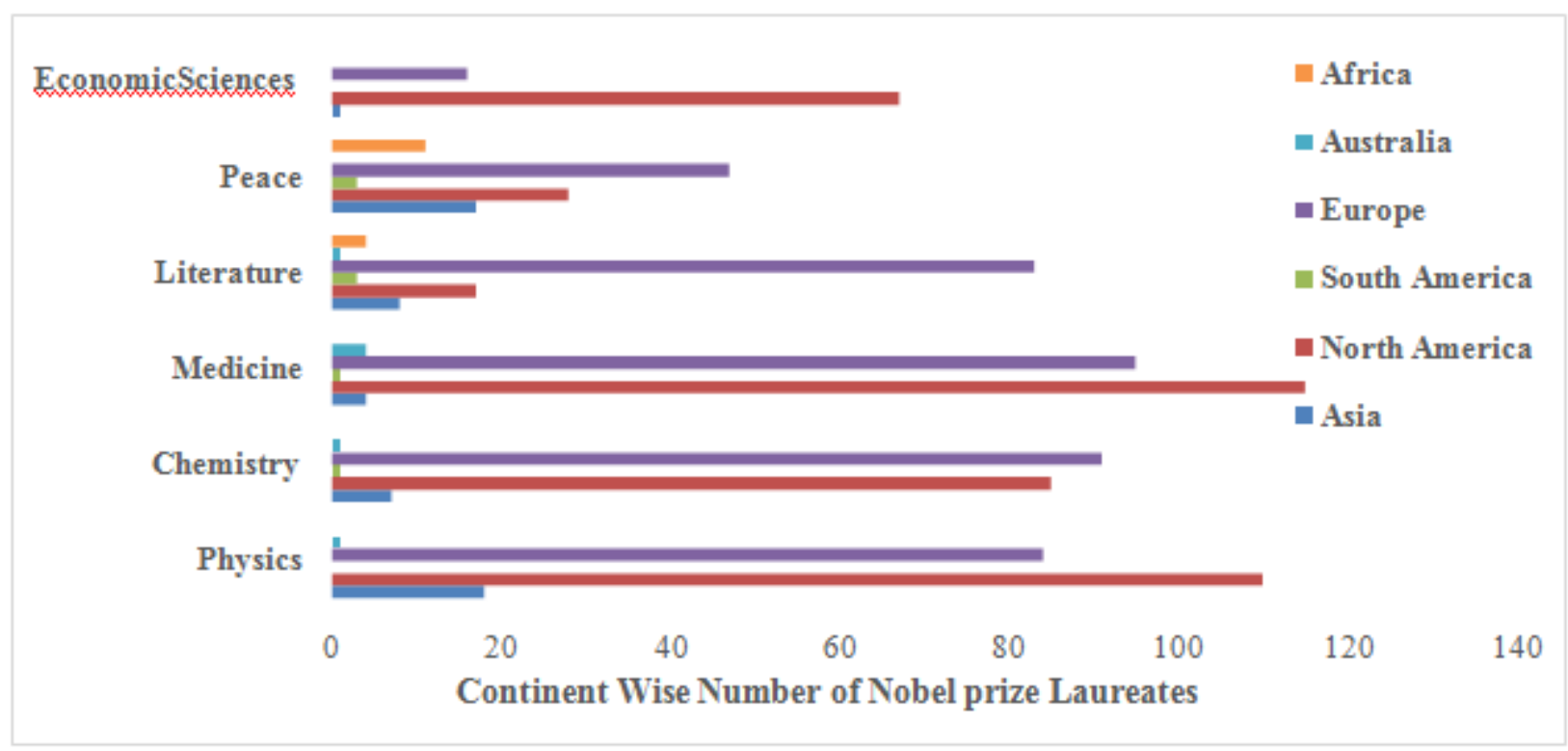

Fig. 2 Continent Wise Nobel Prize Laureates of all categories across the World

North American laureates were dominant in the physics, medicine and economic sciences. However, European laureates were dominant in chemistry, literature and peace (Fig. 2).

The study found that most of the Nobel Prize laureates in physics, medicine, chemistry, literature, peace and economic sciences belonged to North America and Europe when compared to other continents. This is due to the scientific advancements, R\&D investments, industrialization and dominance of Nobel laureates from US (North America), UK, Germany and France (Europe). The study of these four nations published in Royal Society Open Science, covers the entire period since the Swedish Academy first awarded the prize in $1901^{12}$. South America, Africa and Australia laureates awarded very less in all disciplines.

Nobel Prize Organizations:

Nobel Prize has given to 27 times to organizations in peace during the period from 1901 to 2019. International Committee of the Red Cross has awarded 3 times Nobel Prize in peace during the period 1917, 1944 and 1963. UNHCR (Office of the United Nations High Commissioner for Refugees) has awarded 2 times Nobel Prize in peace during the period 1954 and 1981.

The study found that Nobel Prize Laureates in peace of Europe were greater than North America. Organizations awarded Nobel Prize due to their work in elimination of using nuclear weapons in military, democracy and integrity of humanitarian, non-violence and socio- economic development.

\section{Country Wise Nobel Laureates Trends in six different disciplines (1901 to 2019):}

\section{Country Wise Nobel Prize Laureates in Physics (1901 to 2019):}

Total Nobel Prize awards in physics have given to 213 laureates. Out of which, 106 USA, 25 UK, 18 Germany and 15 France laureates awarded in physics, which was accounted to be 49.77, 11.74, 8.45 and 7.04 per cent, respectively (Table 1). 162 laureates awarded during $20^{\text {th }}$ century, whereas 51 laureates awarded in physics during $21^{\text {st }}$ century. 
Table 1: Country Wise Nobel Prize Laureates in Physics during $20^{\text {th }}$ and $21^{\text {st }}$ century

\begin{tabular}{|l|c|c|c|c|c|c|}
\hline Country & \multicolumn{2}{|c|}{$\begin{array}{c}\mathbf{2 0}^{\text {th }} \text { century } \\
(\mathbf{1 9 0 1} \text { to 2000) }\end{array}$} & \multicolumn{2}{c|}{$\begin{array}{c}\mathbf{2 1}^{\text {st }} \text { century } \\
\mathbf{( 2 0 0 1} \text { to 2019) }\end{array}$} & \multicolumn{2}{c|}{$\begin{array}{c}\text { Total } \\
(1901 \text { to 2019) }\end{array}$} \\
\cline { 2 - 7 } & $\begin{array}{c}\text { Number of } \\
\text { Laureates }\end{array}$ & $\begin{array}{c}\text { Percentage to } \\
\text { total }\end{array}$ & $\begin{array}{c}\text { Number of } \\
\text { Laureates }\end{array}$ & $\begin{array}{c}\text { Percentage to } \\
\text { total }\end{array}$ & $\begin{array}{c}\text { Number of } \\
\text { Laureates }\end{array}$ & $\begin{array}{c}\text { Percentage to } \\
\text { total }\end{array}$ \\
\hline France & 12 & 7.41 & 3 & 5.88 & 15 & 7.04 \\
\hline Germany & 16 & 9.88 & 2 & 3.92 & 18 & 8.45 \\
\hline UK & 22 & 13.58 & 3 & 5.88 & 25 & 11.74 \\
\hline USA & 77 & 47.53 & 29 & 56.86 & 106 & 49.77 \\
\hline Others & 35 & 21.6 & 14 & 27.46 & 49 & 23 \\
\hline World & $\mathbf{1 6 2}$ & $\mathbf{1 0 0 . 0 0}$ & $\mathbf{5 1}$ & $\mathbf{1 0 0 . 0 0}$ & $\mathbf{2 1 3}$ & $\mathbf{1 0 0 . 0 0}$ \\
\hline
\end{tabular}

Source: Nobel Prize Organization (www.nobelprize.org);

USA has shown an increasing with mixed trends in Nobel Prize of physics (Fig. 3).

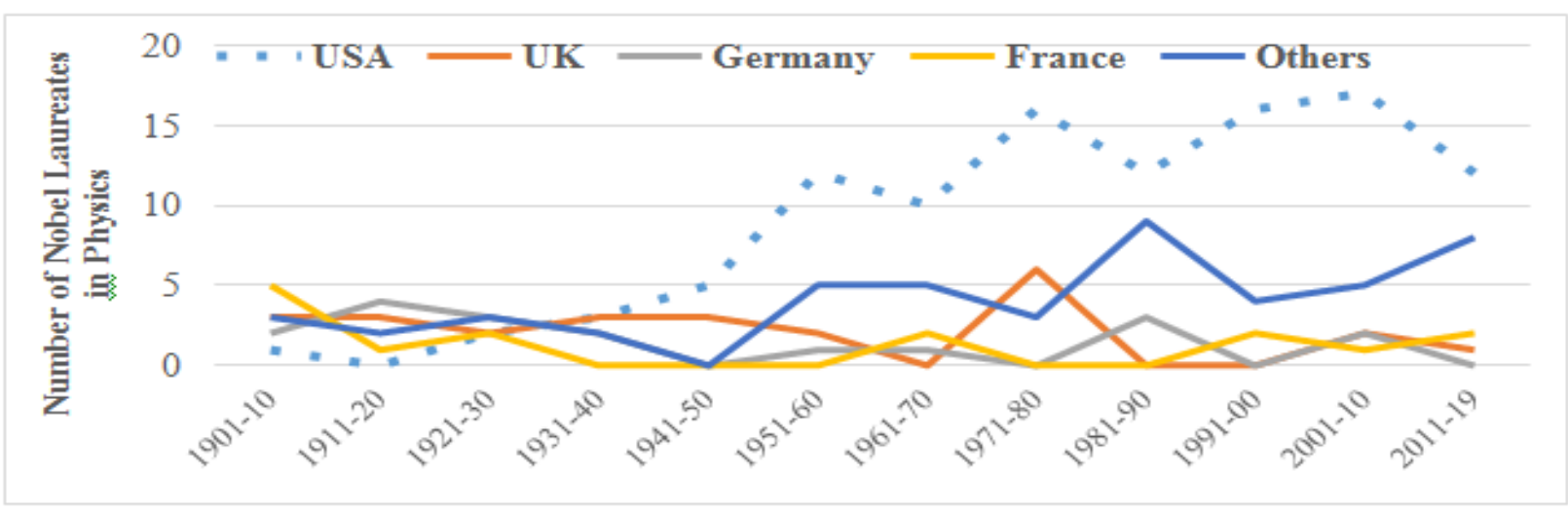

Fig. 3 Trends of USA, UK, Germany \& France Nobel Prize Laureates in Physics

The study revealed that Nobel Prize laureates in physics had found to be more from USA followed by UK, Germany and France. This is due to USA is strong historic investment in basic science, academic freedom for researchers and patience to see results ${ }^{13}$.

Country Wise Nobel Prize Laureates in Chemistry (1901 to 2019):

Total Nobel Prize awards in chemistry have given to 184 laureates during the period of 1901 to 2019. Out of them, 82 USA (44.57\%), 30 Germany (16.30\%), 29 UK (15.76) and 9 France (4.89\%) laureates awarded Nobel Prize in chemistry (Table 2). 139 laureates received Nobel Prize during $20^{\text {th }}$ century whereas, 45 laureates received Nobel Prize in chemistry during $21^{\text {st }}$ century.

Table 2: Country Wise Nobel Prize Laureates in Chemistry during $20^{\text {th }}$ and $21^{\text {st }}$ Century

\begin{tabular}{|l|c|c|c|c|c|c|}
\hline Country & \multicolumn{2}{|c|}{$\begin{array}{c}\mathbf{2 0}^{\text {th }} \text { century } \\
(\mathbf{1 9 0 1} \text { to 2000) }\end{array}$} & \multicolumn{2}{c|}{$\begin{array}{c}\mathbf{2 1}^{\text {st }} \text { century } \\
\mathbf{2 0 0 1}^{\text {to 2019) }}\end{array}$} & \multicolumn{2}{c|}{$\begin{array}{c}\text { Total } \\
\text { (1901 to 2019) }\end{array}$} \\
\cline { 2 - 7 } & $\begin{array}{c}\text { Number of } \\
\text { Laureates }\end{array}$ & $\begin{array}{c}\text { Percentage to } \\
\text { total }\end{array}$ & $\begin{array}{c}\text { Number of } \\
\text { Laureates }\end{array}$ & $\begin{array}{c}\text { Percentage to } \\
\text { total }\end{array}$ & $\begin{array}{c}\text { Number of } \\
\text { Laureates }\end{array}$ & $\begin{array}{c}\text { Percentage to } \\
\text { total }\end{array}$ \\
\hline France & 7 & 5.04 & 2 & 4.44 & 9 & 4.89 \\
\hline Germany & 28 & 20.14 & 2 & 4.44 & 30 & 16.30 \\
\hline UK & 25 & 17.99 & 4 & 8.89 & 29 & 15.76 \\
\hline USA & 51 & 36.69 & 31 & 68.89 & 82 & 44.57 \\
\hline Others & 28 & 20.14 & 6 & 13.34 & 34 & 18.48 \\
\hline World & $\mathbf{1 3 9}$ & $\mathbf{1 0 0 . 0 0}$ & $\mathbf{4 5}$ & $\mathbf{1 0 0 . 0 0}$ & $\mathbf{1 8 4}$ & $\mathbf{1 0 0 . 0 0}$ \\
\hline
\end{tabular}

Source: Nobel Prize Organization (www.nobelprize.org) 


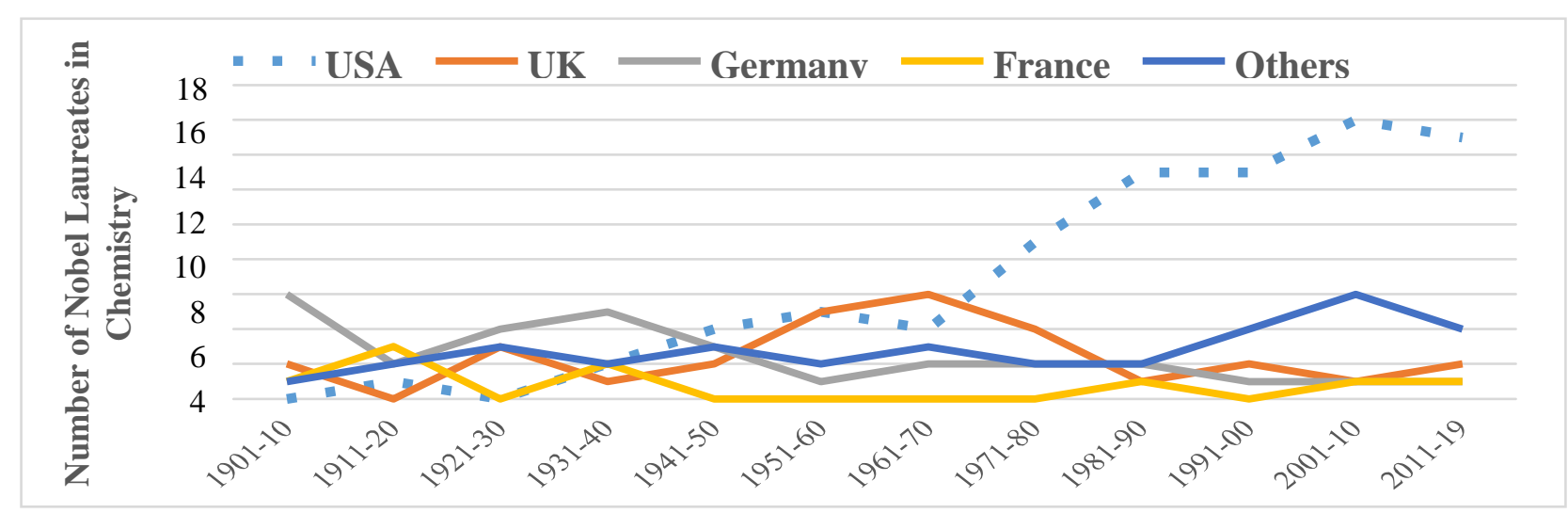

Fig. 4 Trends of USA, UK, Germany \& France Nobel Prize Laureates in Chemistry

USA has shown increasing trends whereas, other nations UK, Germany and France has shown mixed trends in Nobel Prize of chemistry (Fig. 4). The study revealed that Nobel laureates in chemistry had found to be more from USA followed by Germany, UK and France. The USA owes ample to its impressive lead in research scientifically, including advancement of technology, prosperity and security ${ }^{14,15}$.

\section{Country Wise Nobel Prize Laureates Trends in Medicine or Physiology (1901 to 2019):}

Total 219 Laureates took Nobel Prize in medicine during the period of 1901 to 2019. Out of which, 113 USA, 30 UK, 15 Germany and 11 France laureates got Nobel Prize in physiology or medicine which accounted to 51.60, 13.70, 6.85 and 5.02 per cent (Table 3). 172 laureates received Nobel Prize during $20^{\text {th }}$ century whereas, 47 laureates received Nobel Prize in physiology or medicine during $21^{\text {st }}$ century.

Table 3: Country Wise Nobel Prize Laureates in Medicine during $20^{\text {th }}$ and $21^{\text {st }}$ Century

\begin{tabular}{|l|c|c|c|c|c|c|}
\hline Country & \multicolumn{2}{|c|}{$\begin{array}{c}\text { 20th century } \\
(1901 \text { to 2000) }\end{array}$} & \multicolumn{2}{c|}{$\begin{array}{c}\text { 21st century } \\
\text { (2001 to 2019) }\end{array}$} & \multicolumn{2}{c|}{$\begin{array}{c}\text { Total } \\
\text { (1901 to 2019) }\end{array}$} \\
\cline { 2 - 7 } & $\begin{array}{c}\text { Number of } \\
\text { Laureates }\end{array}$ & $\begin{array}{c}\text { Percentage to } \\
\text { total }\end{array}$ & $\begin{array}{c}\text { Number of } \\
\text { Laureates }\end{array}$ & $\begin{array}{c}\text { Percentage to } \\
\text { total }\end{array}$ & $\begin{array}{c}\text { Number of } \\
\text { Laureates }\end{array}$ & $\begin{array}{c}\text { Percentage to } \\
\text { total }\end{array}$ \\
\hline France & 8 & 4.65 & 3 & 6.38 & 11 & 5.02 \\
\hline Germany & 14 & 8.14 & 1 & 2.13 & 15 & 6.85 \\
\hline UK & 21 & 12.21 & 9 & 19.15 & 30 & 13.70 \\
\hline USA & 87 & 50.58 & 26 & 55.32 & 113 & 51.60 \\
\hline Others & 42 & 24.42 & 8 & 17.02 & 50 & 22.83 \\
\hline World & $\mathbf{1 7 2}$ & $\mathbf{1 0 0 . 0 0}$ & $\mathbf{4 7}$ & $\mathbf{1 0 0 . 0 0}$ & $\mathbf{2 1 9}$ & $\mathbf{1 0 0 . 0 0}$ \\
\hline
\end{tabular}

Source: Nobel Prize Organization (www.nobelprize.org) 


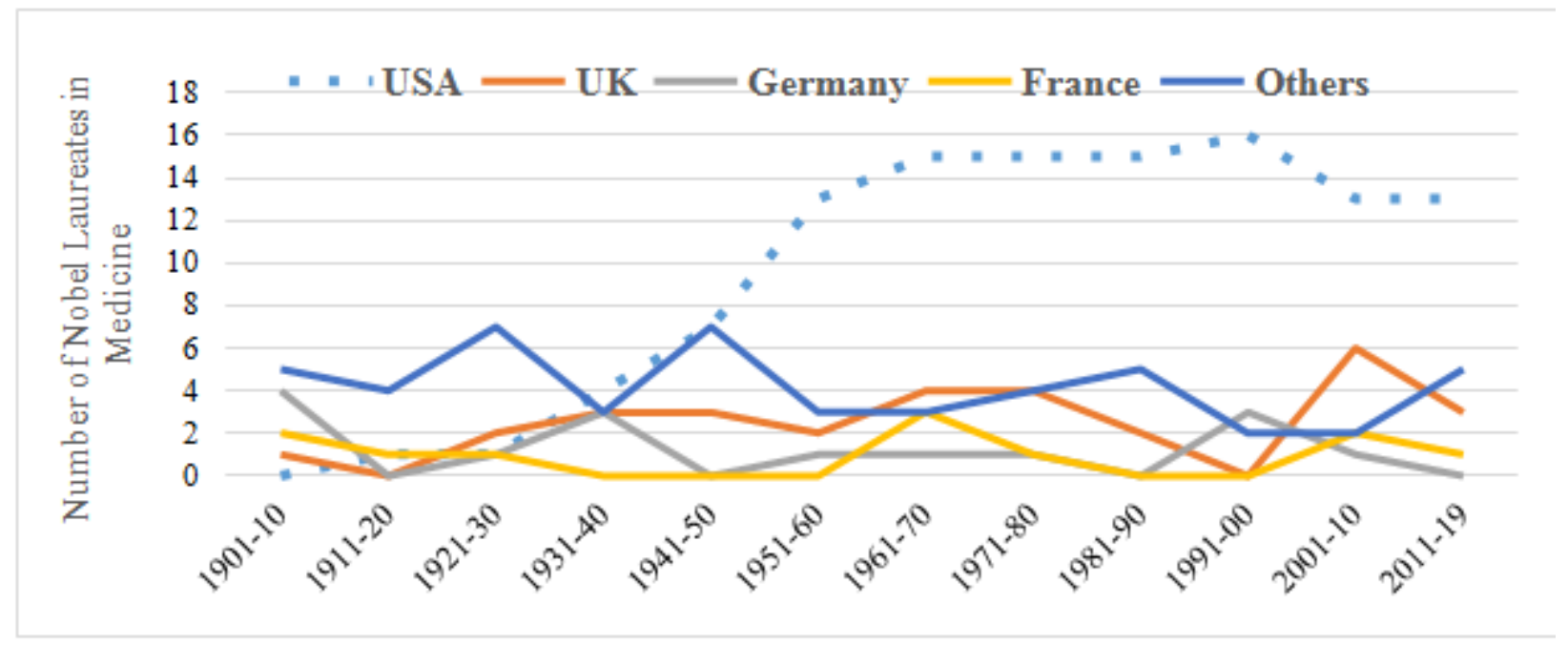

Fig. 5 Trends of USA, UK, Germany \& France Nobel Prize Laureates in Medicine

USA has shown an increasing trend of Nobel Prize laureates in medicine over the years (Fig. 5).

The study found that Nobel Prize laureates in medicine were more from USA followed by UK, Germany and France. US is helpful to uphold its deep grip of science, lavish government support in the form of research grants practically open borders, which mark it potential to generate in the best minds of world. UK entities have all been identified for stupendous contributions in pioneering medical research.

\section{Country Wise Nobel Prize Laureates Trends in Literature (1901 to 2019):}

The total Nobel Prize awards has given to 116 laureates in literature during the period of 1901 to 2019.Out of which, 17 France,12 USA, 11 UK laureates awarded Nobel Prize in literature, which accounted to be 14.66, 10.34 and 9.48 percent respectively (Table 4). 96 laureates received Nobel Prize during $20^{\text {th }}$ century whereas, 20 laureates received Nobel Prize in literature during $21^{\text {st }}$ century.

Number of Nobel Prize laureates from France was more than other countries. However, all four nations have shown mixed trends in literature over the years (Fig. 6).

Table 4: Country Wise Nobel Prize Laureates in Literature during $20^{\text {th }}$ and $21^{\text {st }}$ Century

\begin{tabular}{|l|c|c|c|c|c|c|}
\hline Country & \multicolumn{2}{|c|}{$\begin{array}{c}\mathbf{2 0}^{\text {th }} \text { century } \\
(\mathbf{1 9 0 1} \text { to 2000) }\end{array}$} & \multicolumn{2}{c|}{$\begin{array}{c}\mathbf{2 1}^{\text {st }} \\
\mathbf{( 2 0 0 1} \text { to 2019) }\end{array}$} & \multicolumn{2}{c|}{$\begin{array}{c}\text { Total } \\
\text { (1901 to 2019) }\end{array}$} \\
\cline { 2 - 7 } & $\begin{array}{c}\text { Number of } \\
\text { Laureates }\end{array}$ & $\begin{array}{c}\text { Percentage to } \\
\text { total }\end{array}$ & $\begin{array}{c}\text { Number of } \\
\text { Laureates }\end{array}$ & $\begin{array}{c}\text { Percentage to } \\
\text { total }\end{array}$ & $\begin{array}{c}\text { Number of } \\
\text { Laureates }\end{array}$ & $\begin{array}{c}\text { Percentage to } \\
\text { total }\end{array}$ \\
\hline France & 14 & 14.58 & 3 & 15.00 & 17 & 14.66 \\
\hline Germany & 7 & 7.29 & 1 & 5.00 & 8 & 6.90 \\
\hline UK & 8 & 8.33 & 3 & 15.00 & 11 & 9.48 \\
\hline USA & 11 & 11.46 & 1 & 5.00 & 12 & 10.34 \\
\hline Others & 56 & 58.34 & 12 & 60 & 68 & 58.62 \\
\hline World & $\mathbf{9 6}$ & $\mathbf{1 0 0 . 0 0}$ & $\mathbf{2 0}$ & $\mathbf{1 0 0 . 0 0}$ & $\mathbf{1 1 6}$ & $\mathbf{1 0 0 . 0 0}$ \\
\hline
\end{tabular}

Source: Nobel Prize Organization (www.nobelprize.org) 


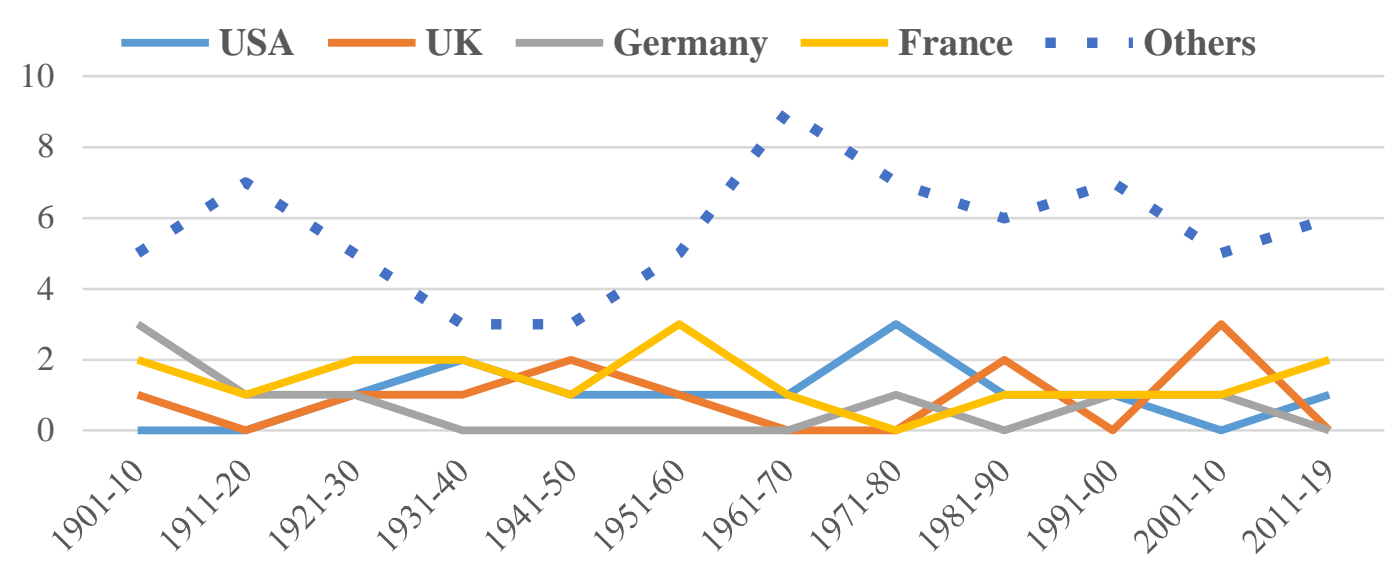

Fig. 6 Trends of USA, UK, Germany \& France Nobel Prize Laureates in Literature

The study found that the other countries got more Nobel Prizes in literature. When compared among four nations, France population has a relatively high IQ in literature. This is mainly due to France scientists have the pro of a cultured education system.

Country Wise Nobel Prize Laureates Trends in Peace (1901 to 2019):

The total Nobel Prize awards have given to 107 laureates in peace during the period of 1901 to 2019. Out of which, 23 USA, 11 UK and 9 France laureates awarded Nobel Prize in peace which accounted to be 21.50, 10.28 and 8.41 per cent, respectively (Table 5). 87 laureates received Nobel Prize during $20^{\text {th }}$ century whereas, 20 laureates received Nobel Prize in peace during $21^{\text {st }}$ century.

Table 5: Country Wise Nobel Prize Laureates in Peace during $20^{\text {th }}$ and $21^{\text {st }}$ Century

\begin{tabular}{|l|c|c|c|c|c|c|}
\hline \multirow{3}{*}{ Country } & \multicolumn{2}{|c|}{$\begin{array}{c}\mathbf{2 0}^{\text {th }} \text { century } \\
(\mathbf{1 9 0 1} \text { to 2000) }\end{array}$} & \multicolumn{2}{c|}{$\begin{array}{c}\mathbf{2 1}^{\text {st }} \text { Century } \\
(\mathbf{2 0 0 1 - 2 0 1 9 )}\end{array}$} & \multicolumn{2}{c|}{$\begin{array}{c}\text { Total } \\
\text { (1901 to 2019) }\end{array}$} \\
\cline { 2 - 7 } & $\begin{array}{c}\text { Number of } \\
\text { Laureates }\end{array}$ & $\begin{array}{c}\text { Percentage to } \\
\text { total }\end{array}$ & $\begin{array}{c}\text { Number of } \\
\text { Laureates }\end{array}$ & $\begin{array}{c}\text { Percentage to } \\
\text { total }\end{array}$ & $\begin{array}{c}\text { Number of } \\
\text { Laureates }\end{array}$ & $\begin{array}{c}\text { Percentage to } \\
\text { total }\end{array}$ \\
\hline France & 9 & 10.34 & 0 & 0 & 9 & 8.41 \\
\hline Germany & 5 & 5.75 & 0 & 0 & 5 & 4.67 \\
\hline UK & 10 & 11.49 & 1 & 5 & 11 & 10.28 \\
\hline USA & 20 & 22.99 & 3 & 15 & 23 & 21.50 \\
\hline Others & 43 & 49.43 & 16 & 80 & 59 & 55.14 \\
\hline World & $\mathbf{8 7}$ & $\mathbf{1 0 0 . 0 0}$ & $\mathbf{2 0}$ & $\mathbf{1 0 0}$ & $\mathbf{1 0 7}$ & $\mathbf{1 0 0 . 0 0}$ \\
\hline
\end{tabular}

Source: Nobel Prize Organization (www.nobelprize.org)

Number of USA, UK, Germany and France Nobel Prize Laureates in peace has shown mixed trends over the years (Fig. 7).

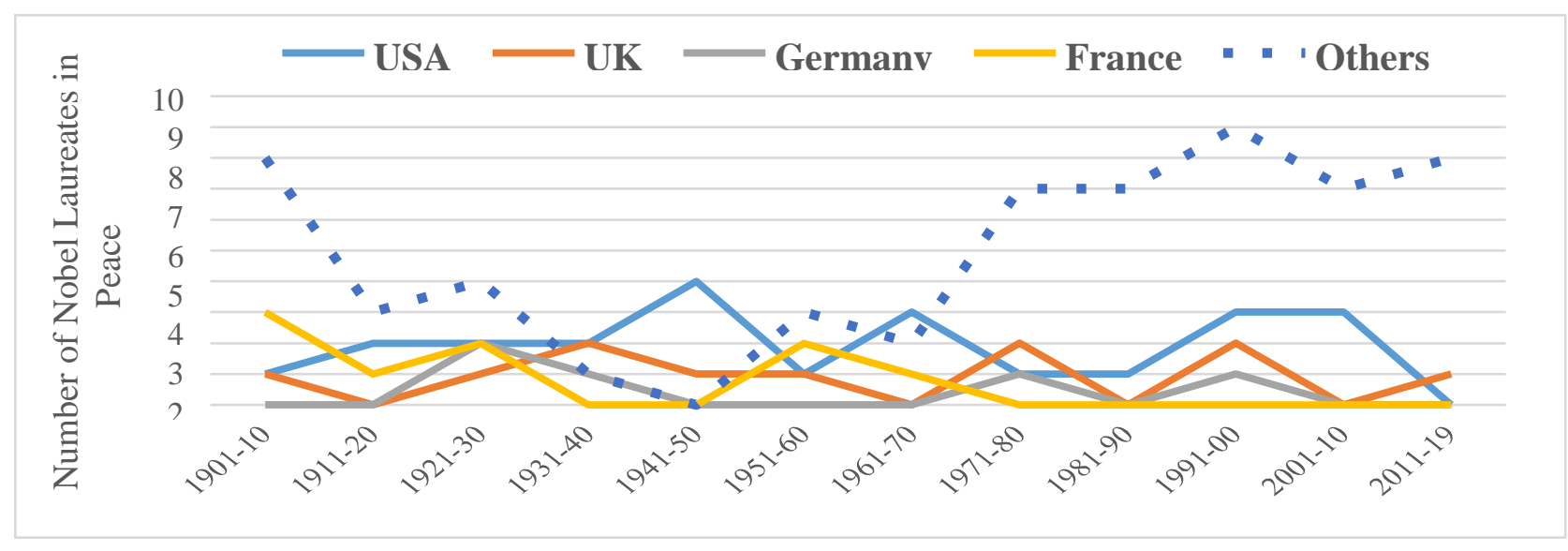

Fig. 7 Trends of USA, UK, Germany \& France Nobel Prize Laureates in Peace 
The study found that others have dominant in Noble prize of peace. This shows the contribution of different activities related to peace such as integration, non-violence, humanity, sustainability, removal of usage of nuclear weapons in military implemented by these nations were more than other nations.

Country Wise Nobel Prize Laureates Trends in Economic Sciences (1901 to 2019):

The total Nobel Prize awards have given to 84 laureates in economic sciences during the period of 1901 to 2019 . Out of 84, USA laureates took the dominant place in economic sciences i.e., 67 times that accounted to be $79.76 \%$ (Table6). 46 laureates received Nobel Prize during 20th century whereas, 38 laureates received Nobel Prize in economic sciences during $21^{\text {st }}$ century.

Table 6: Country Wise Nobel Prize Laureates in Economic Sciences during $20^{\text {th }}$ and $21^{\text {st }}$ century

\begin{tabular}{|c|c|c|c|c|c|c|}
\hline \multirow[t]{2}{*}{ Country } & \multicolumn{2}{|c|}{$\begin{array}{c}20^{\text {th }} \text { century } \\
(1901 \text { to } 2000)\end{array}$} & \multicolumn{2}{|c|}{$\begin{array}{l}\text { 21 }^{\text {st }} \text { Century } \\
(2001-2019)\end{array}$} & \multicolumn{2}{|c|}{$\begin{array}{c}\text { Total } \\
(1901 \text { to } 2019)\end{array}$} \\
\hline & $\begin{array}{l}\text { Number of } \\
\text { Laureates }\end{array}$ & $\begin{array}{c}\text { Percentage to } \\
\text { total }\end{array}$ & $\begin{array}{l}\text { Number of } \\
\text { Laureates }\end{array}$ & $\begin{array}{c}\text { Percentage to } \\
\text { total }\end{array}$ & $\begin{array}{l}\text { Number of } \\
\text { Laureates }\end{array}$ & $\begin{array}{c}\text { Percentage to } \\
\text { total }\end{array}$ \\
\hline France & 1 & 2.17 & 1 & 2.63 & 2 & 2.38 \\
\hline Germany & 1 & 2.17 & 0 & 0.00 & 1 & 1.19 \\
\hline UK & 5 & 10.87 & 1 & 2.63 & 6 & 7.14 \\
\hline USA & 32 & 69.57 & 35 & 92.11 & 67 & 79.76 \\
\hline Others & 7 & 15.22 & 1 & 2.63 & 8 & 9.53 \\
\hline World & 46 & 100.00 & 38 & 100.00 & 84 & 100.00 \\
\hline
\end{tabular}

Source: Nobel Prize Organization (www.nobelprize.org)

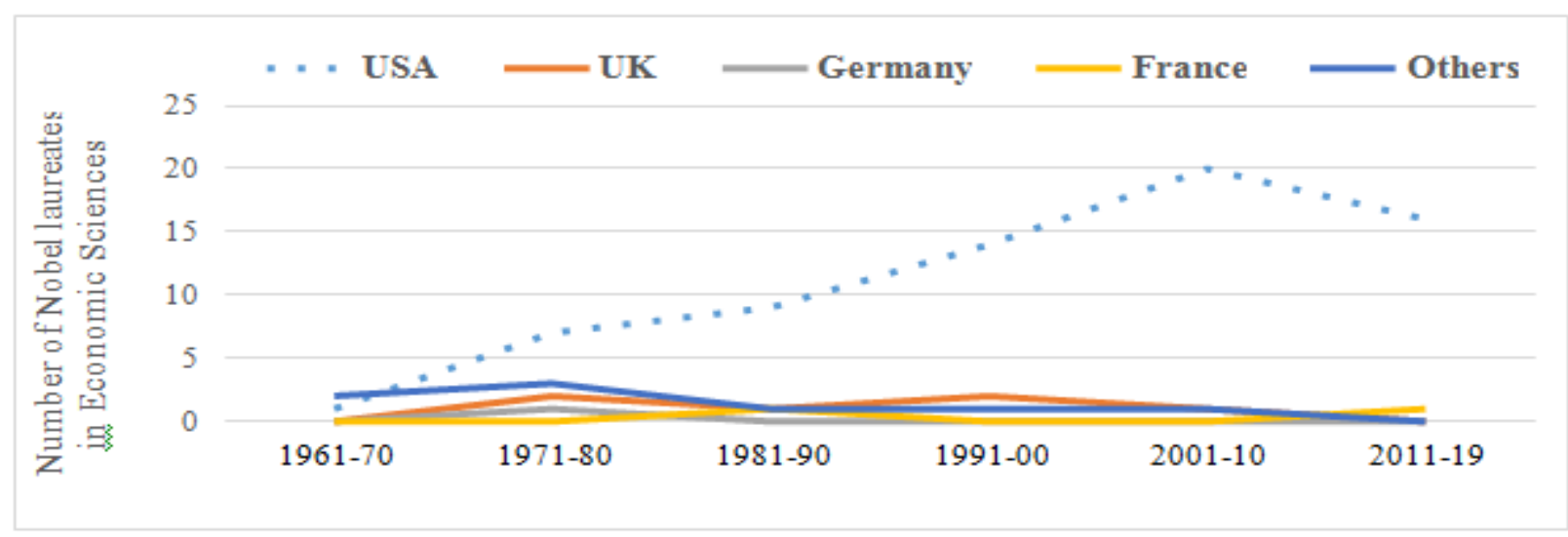

Fig. 8 Trends of USA, UK, Germany \& France Nobel Prize Laureates in Economic Sciences

Number of USA Noble Prize laureates awarded was more in economic sciences and shown increasing trends over the years (Fig. 8).

The study found that USA has solo Nobel Prize taker in economic sciences. This is mainly because of Laureates have introduced new approaches to acquire reliable answers to fight with present day existing problems, which further help in improving the lives of the worst-off people around the world.

\section{Significant Contributions of Laureates in Nobel Prize of Six Different Categories:}

The contribution of physics in France and Germany realized to be more before world war-II. However, the same was more in USA after world war-II. The Laureates in physics worked mostly on optical physics, nuclear physics, quantum mechanics, electro-magnetism, particle physics, astrophysics, condensed matter physics and cosmology (Table7). 
Table 7: Decade Wise Nobel Prize Laureates Significant Contributions on Physics

\begin{tabular}{|c|c|c|c|}
\hline Year & $\begin{array}{l}\text { More Awardees } \\
\text { from }\end{array}$ & Branch of Physics & $\begin{array}{c}\text { Pioneering Discoveries of Nobel Prize Laureates in } \\
\text { Physics }\end{array}$ \\
\hline $\begin{array}{c}1901 \text { to } \\
1910\end{array}$ & France \& Poland & $\begin{array}{l}\text { Optical, Condensed } \\
\text { matter and quantum } \\
\text { physics }\end{array}$ & $\begin{array}{l}\text { Discovery of Remarkable rays, impact of magnetism on radiation } \\
\text { phenomena, spontaneous radioactivity, argon, cathode rays, electricity } \\
\text { conduction with the help of gases, spectroscopic and metrological } \\
\text { investigations, interference phenomenon, wireless telegraphy, and the } \\
\text { equation for liquids and gaseous state. }\end{array}$ \\
\hline $\begin{array}{c}1911 \text { to } \\
1920\end{array}$ & $\begin{array}{l}\text { UK, Russia \& } \\
\text { Germany }\end{array}$ & $\begin{array}{l}\text { Optical and nuclear } \\
\text { physics }\end{array}$ & $\begin{array}{l}\text { Discovery of heat radiation, automatic regulators, X-rays diffraction by } \\
\text { crystals, analysis of crystal structure, characteristic elements of the } \\
\text { Rontgen radiation, energy quanta, Doppler effect, and steel alloys } \\
\text { anomalies in nickel. }\end{array}$ \\
\hline $\begin{array}{c}1921 \text { to } \\
1930\end{array}$ & $\begin{array}{l}\text { Germany, USA \& } \\
\text { France }\end{array}$ & $\begin{array}{l}\text { Quantum Mechanics and } \\
\text { Theoretical physics }\end{array}$ & $\begin{array}{l}\text { Discovery of photoelectric effect laws, the structure of atoms, } \\
\text { elementary charge of electricity, X-ray spectroscopy, influence of an } \\
\text { electron on an atom, discontinuous structure of matter, thermionic } \\
\text { phenomenon, wave nature of electrons, and scattering of light. }\end{array}$ \\
\hline $\begin{array}{c}1931 \text { to } \\
1940\end{array}$ & UK \& USA & $\begin{array}{c}\text { Optical Physics, } \\
\text { Quantum mechanics and } \\
\text { radiology }\end{array}$ & $\begin{array}{l}\text { Discovery of } \mathrm{H} 2 \text { allotropic forms, atomic theory new production forms, } \\
\text { neutron, cosmic radiation, diffraction of electrons by crystals, new } \\
\text { radioactive elements existence, and the cyclotron. }\end{array}$ \\
\hline $\begin{array}{c}1941 \text { to } \\
1950\end{array}$ & UK \& Hungary & Nuclear physics & $\begin{array}{l}\text { Development of the molecular ray method, proton magnetic moment, } \\
\text { recording atomic nuclei magnetic properties, Pauli Principle, generation } \\
\text { of extremely high pressures, Appleton layer, Wilson cloud chamber } \\
\text { method, existence of mesons, and photographic method. }\end{array}$ \\
\hline $\begin{array}{c}1951 \text { to } \\
1960\end{array}$ & $\begin{array}{c}\text { Germany, } \\
\text { Switzerland \&USA }\end{array}$ & $\begin{array}{l}\text { Nuclear Physics and } \\
\text { Electromagnetism }\end{array}$ & $\begin{array}{l}\text { Development of transmutation of atomic nuclei, nuclear magnetic } \\
\text { precision methods and measurements, phase contrast method } \\
\text { demonstration, statistical interpretation of wave function, } \mathrm{H} 2 \text { spectrum } \\
\text { fine structure, electron magnetic moment, effect of transistor, parity } \\
\text { laws, interpretation of the Cherenkov effect, antiproton and bubble } \\
\text { chamber. }\end{array}$ \\
\hline $\begin{array}{c}1961 \\
\text { to } \\
1970\end{array}$ & 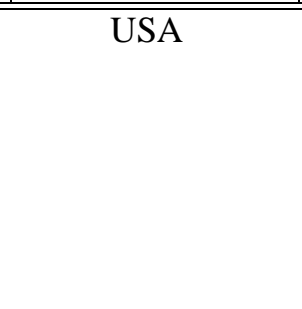 & $\begin{array}{l}\text { Particle Physics plasma } \\
\text { physics, quantum } \\
\text { physics, astrophysics } \\
\text { and solid state physics } \\
\end{array}$ & $\begin{array}{l}\text { Development of Magneto-hydro-dynamics, electron scattering in } \\
\text { atomic nuclei, liquid helium theories, atomic nucleus and the } \\
\text { elementary particles theories, oscillators and amplifiers construction } \\
\text { on the basis of maser-laser principle, elementary particles } \\
\text { consequences, Hertzian resonances in atoms, energy production in } \\
\text { stars, a large number of resonance states, elementary particles } \\
\text { interactions, magneto-hydro-dynamics, and anti-ferromagnetism. }\end{array}$ \\
\hline $\begin{array}{c}1971 \\
\text { to } \\
1980\end{array}$ & USA & $\begin{array}{l}\text { Electromagnetism, } \\
\text { astrophysics and nuclear } \\
\text { physics }\end{array}$ & $\begin{array}{l}\text { Discovery of Holographic method, theory of superconductivity, } \\
\text { tunneling phenomena in semiconductors \& superconductors, aperture } \\
\text { synthesis technique \& pulsars, structure of the atomic nucleus theory, } \\
\text { new kind of heavy elementary particle, magnetic \& disordered } \\
\text { systems electronic structure, area of low- temperature physics, the } \\
\text { unified weak and electro-magnetic interaction theory, and neutral K- } \\
\text { mesons decay. }\end{array}$ \\
\hline $\begin{array}{l}1981 \\
\text { to } \\
1990\end{array}$ & $\begin{array}{l}\text { Netherlands, USA \& } \\
\text { Sweden }\end{array}$ & $\begin{array}{c}\text { Spectroscopy } \\
\text { astrophysics, Quantum } \\
\text { Mechanics and particle } \\
\text { physics }\end{array}$ & $\begin{array}{l}\text { Development of Laser spectroscopy, high-resolution spectroscopy of } \\
\text { electron, critical phenomena in connection with phase transitions, } \\
\text { stars evolution and structure, field particles } \mathrm{W} \text { and } \mathrm{Z} \text {, quantized Hall } \\
\text { effect, electron optics, superconductivity in ceramic materials, muon } \\
\text { neutrino, separated oscillatory fields method, ion trap technique, and } \\
\text { Quark model. }\end{array}$ \\
\hline
\end{tabular}




\begin{tabular}{|c|c|c|c|}
\hline $\begin{array}{c}1991 \\
\text { to } \\
2000\end{array}$ & USA & $\begin{array}{l}\text { Nuclear, Quantum and } \\
\text { Condensed matter } \\
\text { physics }\end{array}$ & $\begin{array}{l}\text { Discovery of order phenomenon in liquid crystals \& polymers, } \\
\text { particle detectors, neutron scattering techniques, new type of pulsar, } \\
\text { lepton physics, cool \& trap atoms with laser light, super-fluidity in } \\
\text { helium-3Quantum structure of electroweak interactions, quantum } \\
\text { fluid with fractionally charged excitations, ICT, and opto-electronics. }\end{array}$ \\
\hline $\begin{array}{c}2001 \\
\text { to } \\
2010\end{array}$ & USA, Japan \& Italy & Cosmology & $\begin{array}{l}\text { Detection of cosmic neutrinos, optical communication, symmetry in } \\
\text { subatomic physics, condensation of alkali atoms in dilute gases, } \\
\text { Giant Magneto-resistance, blackbody form \& anisotropy, optical } \\
\text { coherence, asymptotic freedom in strong interaction, } \\
\text { superconductors theories, and super-fluids Graphene. }\end{array}$ \\
\hline $\begin{array}{c}2011 \\
\text { to } \\
2019\end{array}$ & USA & $\begin{array}{l}\text { Optical Physics, laser } \\
\text { physics Quantum } \\
\text { physics }\end{array}$ & $\begin{array}{l}\text { Development of distant supernovae observations, individual quantum } \\
\text { systems measurement \& manipulation, understanding the origin of } \\
\text { mass, light emitting diodes, neutrino oscillations, quantum matter, } \\
\text { astronomy, manufacturing, and evolution of universe. }\end{array}$ \\
\hline
\end{tabular}

Source: Nobel Prize Organization (www.nobelprize.org)

The study found that the discoveries of physics helps to play an important role for the future progress of people and also generates an essential knowledge required for the technological advances in future, which leads to initiative the economic growth of the universe.

Table 8: Decade Wise Nobel Prize Laureates Significant Contribution on Chemistry

\begin{tabular}{|c|c|c|c|}
\hline Year & $\begin{array}{l}\text { More } \\
\text { Awardees } \\
\text { from }\end{array}$ & Branch of Chemistry & $\begin{array}{c}\text { Pioneering Discoveries of Nobel Prize Laureates in } \\
\text { Chemistry }\end{array}$ \\
\hline $\begin{array}{c}1901 \text { to } \\
1910\end{array}$ & $\begin{array}{l}\text { Russia \& } \\
\text { Germany }\end{array}$ & $\begin{array}{c}\text { Organic, analytical chemistr } \\
\text { and Biochemistry }\end{array}$ & $\begin{array}{l}\text { Discovery of dynamic chemical laws \& osmotic pressure, purine } \\
\text { sugar syntheses, theory of electrolytic dissociation, inert gaseou } \\
\text { elements in air, organic dyes\& hydro-aromatic compounds } \\
\text { isolation of the element fluorine, cell-free fermentation } \\
\text { disintegration of the elements, work on catalysis, and alicycli } \\
\text { compounds. }\end{array}$ \\
\hline $\begin{array}{c}1911 \text { to } \\
1920\end{array}$ & $\begin{array}{l}\text { Germany \& } \\
\text { France }\end{array}$ & $\begin{array}{l}\text { Organic, Analytical and } \\
\text { inorganic chemistry }\end{array}$ & $\begin{array}{l}\text { Discovery of Radium \& polonium, Grignard reagent, linkage o } \\
\text { atoms in molecules, atomic weight of large elements, chlorophy } \\
\text { pigment, synthesis of ammonia, and Thermo-chemistry. }\end{array}$ \\
\hline $\begin{array}{c}1921 \text { to } \\
1930\end{array}$ & $\begin{array}{c}\text { Germany \& } \\
\text { UK }\end{array}$ & $\begin{array}{c}\text { Biochemistry and Physical } \\
\text { chemistry }\end{array}$ & $\begin{array}{l}\text { Development of origin and nature of isotopes, mass spectrograph, } \\
\text { micro-analysis method of organic substances, demonstration of the } \\
\text { heterogeneous nature of colloid solutions, disperse systems, bile } \\
\text { acids \& related substances constitution, sterols constitution \& their } \\
\text { connection with the vitamins, fermentation of sugar, fermentative } \\
\text { enzymes \& constitution of haemin, and chlorophyll. }\end{array}$ \\
\hline $\begin{array}{c}1931 \text { to } \\
1940\end{array}$ & $\begin{array}{l}\text { Germany, } \\
\text { France \& } \\
\text { USA }\end{array}$ & $\begin{array}{c}\text { Biochemistry, Inorganic and } \\
\text { physical chemistry }\end{array}$ & $\begin{array}{l}\text { Development of surface chemistry, chemical high pressure } \\
\text { methods, heavy H2, new radioactive elements, dipole moments, X- } \\
\text { rays diffraction \& electrons in gases, found carbohydrates \& } \\
\text { vitamin C, carotenoids and vitamins, sex hormones, and poly- } \\
\text { methylene's \& higher terpenes. }\end{array}$ \\
\hline $\begin{array}{c}1941 \text { to } \\
1950\end{array}$ & $\begin{array}{c}\text { Germany \& } \\
\text { USA }\end{array}$ & $\begin{array}{l}\text { Biochemistry, Analytical } \\
\text { Chemistry and Thermo- } \\
\text { chemistry }\end{array}$ & $\begin{array}{l}\text { Use of isotopes as tracers, fission of heavy nuclei, agricultural \& } \\
\text { nutrition chemistry, high-pressure physics, biological importance of } \\
\text { alkaloids, electrophoresis, and adsorption analysis \& diene } \\
\text { synthesis. }\end{array}$ \\
\hline
\end{tabular}




\begin{tabular}{|c|c|c|c|}
\hline $\begin{array}{c}1951 \text { to } \\
1960\end{array}$ & USA \& UK & $\begin{array}{l}\text { Biochemistry, Inorganic, } \\
\text { Theoretical and physical } \\
\text { chemistry }\end{array}$ & $\begin{array}{l}\text { The chemistry of the trans-uranium elements, partition } \\
\text { chromatography, nature of the chemical bond, biochemically } \\
\text { important sulphur compounds, mechanism of chemical reactions, } \\
\text { nucleotides \& nucleotide co- enzymes, structure of insulin, } \\
\text { polarographic analysis methods, and carbon-14 for age } \\
\text { determination. }\end{array}$ \\
\hline $\begin{array}{c}1961 \text { to } \\
1970\end{array}$ & $\begin{array}{c}\text { USA, UK \& } \\
\text { Germany }\end{array}$ & $\begin{array}{l}\text { Biochemistry, Theoretical } \\
\text { and physical chemistry }\end{array}$ & $\begin{array}{l}\text { Discovered Co2 assimilation in plants, structures of globular } \\
\text { proteins, high polymers technology, X-ray techniques in } \\
\text { biochemical substances, organic synthesis, molecular orbital } \\
\text { method, extremely fast chemical reactions, reciprocal relations, and } \\
\text { concept of conformation \& sugar nucleotides. }\end{array}$ \\
\hline $\begin{array}{c}1971 \text { to } \\
1980\end{array}$ & $\begin{array}{c}\text { USA, UK \& } \\
\text { Germany }\end{array}$ & $\begin{array}{c}\text { Biochemistry, } \\
\text { stereochemistry and } \\
\text { Inorganic chemistry }\end{array}$ & $\begin{array}{l}\text { Discovered geometry and electronic structure of molecules, ribo- } \\
\text { nuclease, catalytic activity and chemical of the active centre of the } \\
\text { ribo-nuclease molecule, sandwich compounds, physical chemistry } \\
\text { of the macromolecules, enzyme-catalyzed reactions, structure of } \\
\text { boranes, theory of dissipative structures, chemiosmotic theory } \\
\text { formulation, boron \& phosphorus-containing useful compounds, } \\
\text { nucleic acids biochemistry, and base sequences determination in } \\
\text { nucleic acids. }\end{array}$ \\
\hline $\begin{array}{c}1981 \text { to } \\
1990\end{array}$ & \begin{tabular}{|c|} 
USA, \\
Germany \& \\
Canada
\end{tabular} & $\begin{array}{l}\text { Biochemistry and Physical } \\
\text { Chemistry }\end{array}$ & $\begin{array}{l}\text { Discovered chemical reactions, crystallographic electron } \\
\text { microscopy, mechanisms of electron transfer reactions, chemical } \\
\text { synthesis methodology on a solid matrix, determination of crystal } \\
\text { structures, dynamics of chemical elementary processes, structure- } \\
\text { specific high selectivity interactions, photosynthetic reaction center } \\
\text { three-dimensional structure, catalytic properties of RNA, and } \\
\text { organic synthesis theory and methodology. }\end{array}$ \\
\hline $\begin{array}{c}1991 \text { to } \\
2000\end{array}$ & USA \& UK & $\begin{array}{c}\text { Biochemistry, Physical } \\
\text { Chemistry and Organic } \\
\text { Chemistry }\end{array}$ & $\begin{array}{l}\text { Discovered high-resolution NMR spectroscopy methodology, } \\
\text { theory of electron transfer reactions, PCR, carbo cation chemistry, } \\
\text { atmospheric chemistry, fullerenes, ATP synthesis, an ion- } \\
\text { transporting enzyme, theory functional density, methods of } \\
\text { computation in quantum chemistry, femto second spectroscopy, and } \\
\text { conductive polymers. }\end{array}$ \\
\hline $\begin{array}{c}2001 \text { to } \\
2010\end{array}$ & $\begin{array}{c}\text { USA, Japan } \\
\text { and Israel }\end{array}$ & $\begin{array}{c}\text { Biochemistry, Organic } \\
\text { Chemistry and Physical } \\
\text { Chemistry }\end{array}$ & $\begin{array}{l}\text { Discovered chirally catalyzed hydrogenation \& oxidation reactions, } \\
\text { identification \& structure analyses of biological macromolecules, } \\
\text { concerning channels in cell membranes, ubiquitin-mediated protein } \\
\text { degradation, metathesis method in organic synthesis, molecular } \\
\text { basis of eukaryotic transcription, chemical processes on solid } \\
\text { surfaces, green fluorescent protein, ribosome structure \& function, } \\
\text { and cross couplings of palladium-catalyzation in organic synthesis. }\end{array}$ \\
\hline $\begin{array}{c}2011 \text { to } \\
2019\end{array}$ & USA \& UK & $\begin{array}{c}\text { Biochemistry and Physical } \\
\text { Chemistry }\end{array}$ & $\begin{array}{l}\text { Discovery of quasi crystals, G-protein-coupled receptors, multi- } \\
\text { scale models for complex chemical systems, super-resolved } \\
\text { fluorescence microscopy, mechanistic studies of DNA repair, } \\
\text { design and synthesis of molecular machines, cryo-electron } \\
\text { microscopy, directed evolution of enzymes and development of } \\
\text { lithium-ion batteries. }\end{array}$ \\
\hline
\end{tabular}

Source: Nobel Prize Organization (www.nobelprize.org)

The contribution of Germany laureates in chemistry found to be more before world war-II. Nevertheless, USA laureates have dominated more in chemistry after world war-II. The chemistry laureates found new discoveries on the areas of organic, inorganic, physical, biochemistry, analytical and theoretical chemistry (Table 8). The study found that the inventions of chemistry needs to solve many future problems such as controlling our environmental conditions, providing safe drinking water facilities, food production, and promoting human well-being.

Table 9: Decade Wise Nobel Prize Laureates Significant Contribution on Medicine

\begin{tabular}{|c|c|c|c|}
\hline Year & $\begin{array}{c}\text { More } \\
\text { Awardees } \\
\text { from }\end{array}$ & Branches of Medicine & $\begin{array}{c}\text { Pioneering Contribution of Nobel Prize Laureates } \\
\text { in Medicine }\end{array}$ \\
\hline
\end{tabular}




\begin{tabular}{|c|c|c|c|}
\hline $\begin{array}{l}1901 \\
\text { to } \\
1910\end{array}$ & Germany & Epidemiology and Physiology & $\begin{array}{l}\text { Worked on serum therapy, malaria, treatment of lupus vulgaris } \\
\text { diseases, physiology of digestion, tuberculosis, structure of the } \\
\text { nervous system, protozoa in causing diseases, disintegration of } \\
\text { the elements, the chemistry of radioactive substances, } \\
\text { physiology, pathology \& surgery of the thyroid gland and } \\
\text { proteins. }\end{array}$ \\
\hline $\begin{array}{c}1911 \\
\text { to } \\
1920\end{array}$ & France & $\begin{array}{l}\text { Hematology and } \\
\text { Patho-physiology }\end{array}$ & $\begin{array}{l}\text { Worked on dioptrics of the eye, vascular structure and the } \\
\text { transplantation of blood vessels \& organs, anaphylaxis, } \\
\text { vestibular apparatus physiology \& pathology, immunity, and } \\
\text { capillary motor regulating mechanism. }\end{array}$ \\
\hline $\begin{array}{c}1921 \\
\text { to } \\
1930\end{array}$ & UK \& Austria & $\begin{array}{l}\text { Epidemiology, Biochemistry } \\
\text { and Molecular Biology }\end{array}$ & $\begin{array}{l}\text { Worked on production of heat in the muscle, relationship } \\
\text { between the metabolism of lactic acid in the muscle \& the } \\
\text { consumption of } \mathrm{O} 2 \text {, insulin, electrocardiogram mechanism, } \\
\text { Spiroptera carcinoma, value of malaria inoculation therapy, } \\
\text { typhus, anti-neurotic \& growth-stimulating vitamins, and } \\
\text { human blood groups. }\end{array}$ \\
\hline $\begin{array}{c}1931 \\
\text { to } \\
1940\end{array}$ & $\begin{array}{c}\text { UK \& } \\
\text { Germany }\end{array}$ & Physiology & $\begin{array}{l}\text { Worked on nature \& action of the respiratory enzyme, } \\
\text { chromosome in heredity, neurons functions, therapy of anemia } \\
\text { in liver, organizer effect in development of embryo, nerve } \\
\text { impulses transmission, combustion of biological processes of } \\
\text { the catalysis of fumaric acid \& vitamin C, sinus \& aortic } \\
\text { mechanisms, and anti-bacterial effects of prontosil. }\end{array}$ \\
\hline $\begin{array}{l}1941 \\
\text { to } \\
1950\end{array}$ & $\begin{array}{c}\text { USA \& } \\
\text { Switzerland }\end{array}$ & Biochemistry & $\begin{array}{l}\text { Worked on single nerve fibres, penicillin, the X-ray induced } \\
\text { mutations, catalytic conversion of glycogen, anterior pituitary } \\
\text { lobe hormone in the sugar metabolism, DDT high efficiency, } \\
\text { functional organization of the interbrain, leucotomy therapeutic } \\
\text { value in certain psychoses \& hormones structure, and biological } \\
\text { effects of the adrenal cortex. }\end{array}$ \\
\hline $\begin{array}{l}1951 \\
\text { to } \\
1960\end{array}$ & USA & $\begin{array}{l}\text { Physiology, Immunology, } \\
\text { Biochemistry, Epidemiology } \\
\text { and Molecular Biology }\end{array}$ & $\begin{array}{l}\text { Worked on yellow fever, streptomycin, citric acid cycle, co- } \\
\text { enzyme A, ability of poliomyelitis viruses, oxidation enzymes } \\
\text { nature \& mode of action, heart catheterization, synthetic } \\
\text { compounds impact on the skeletal muscles \& vascular system, } \\
\text { genes act regulation, biological synthesis of RNA \& DNA, and } \\
\text { immunological tolerance. }\end{array}$ \\
\hline $\begin{array}{c}1961 \\
\text { to } \\
1970\end{array}$ & $\begin{array}{l}\text { USA \& } \\
\text { Germany }\end{array}$ & $\begin{array}{l}\text { Biochemistry, Microbiology } \\
\text { and Neuroscience }\end{array}$ & $\begin{array}{l}\text { Worked on physical mechanism of the cochlea, molecular } \\
\text { structure of nucleic acids, ionic mechanisms in nerves, } \\
\text { regulation metabolism of the fatty acid, enzyme \& virus } \\
\text { synthesis genetic control, tumour- inducing viruses, prostatic } \\
\text { cancer treatment, chemical \& physiological visual processes in } \\
\text { the eye, genetic code interpretation, conformation \& storage } \\
\text { concept, release, and inactivation of humoral transmitters. }\end{array}$ \\
\hline $\begin{array}{l}1971 \\
\text { to } \\
1980\end{array}$ & $\begin{array}{l}\text { USA, UK \& } \\
\text { Austria }\end{array}$ & $\begin{array}{l}\text { Biochemistry, Epidemiology } \\
\text { and Radiobiology }\end{array}$ & $\begin{array}{l}\text { Worked on mechanism of hormones action, chemical } \\
\text { antibodies structure, individual \& social behavior patterns, } \\
\text { organization of cell structure \& function, interaction between } \\
\text { cell genetic material \& tumour viruses, new mechanisms for the } \\
\text { origin \& dissemination of infectious diseases, production of } \\
\text { peptide hormone in the brain, radio-immunoassays of peptide } \\
\text { hormones, restriction enzymes, computer assisted tomography, } \\
\text { and genetically identified structures on the surface of the cell. }\end{array}$ \\
\hline $\begin{array}{c}1981 \\
\text { to } \\
1990\end{array}$ & $\begin{array}{c}\text { USA, Sweden } \\
\& \text { UK }\end{array}$ & $\begin{array}{l}\text { Epidemiology, Genetics and } \\
\text { Immunology }\end{array}$ & $\begin{array}{l}\text { Worked on information processing in the visual system, } \\
\text { prostaglandins, principles of monoclonal antibodies production, } \\
\text { cholesterol metabolism regulation, growth factors, genetic } \\
\text { principle for antibody generation diversity, principles for } \\
\text { treatment of drugs, cellular origin of retroviral oncogenes, and } \\
\text { organ \& cell transplantation. }\end{array}$ \\
\hline
\end{tabular}




\begin{tabular}{|c|c|c|c|}
\hline $\begin{array}{c}1991 \\
\text { to } \\
2000\end{array}$ & USA \& UK & $\begin{array}{c}\text { Cytology, Bioinformatics and } \\
\text { Genetics }\end{array}$ & $\begin{array}{l}\text { Worked on single ion channels in cells function, reversible } \\
\text { protein phos-phorylation, split genes, G- proteins, development } \\
\text { of early embryonic genetic control, cell mediated immune } \\
\text { defence specificity, prions as a signing molecule in the cardio- } \\
\text { vascular system, intrinsic signals in proteins, and transduction } \\
\text { of signals in the nervous system. }\end{array}$ \\
\hline $\begin{array}{l}2001 \\
\text { to } \\
2010\end{array}$ & USA \& UK & $\begin{array}{c}\text { Biochemistry, Genetics and } \\
\text { Physiology }\end{array}$ & $\begin{array}{l}\text { Worked on cell cycle key regulators, organ development } \\
\text { genetic regulation, the organization \& odorant receptors of the } \\
\text { olfactory system, Helicobacter pylori bacterium, RNA } \\
\text { interference, principles for modification of the specific genes in } \\
\text { mice, cervical cancer caused by human papilloma viruses, } \\
\text { human immunodeficiency virus, telomeres, the enzyme } \\
\text { telomerase, and in vitro fertilization. }\end{array}$ \\
\hline $\begin{array}{c}2011 \\
\text { to } \\
2019\end{array}$ & USA \& Japan & $\begin{array}{c}\text { Cytology, Epidemiology and } \\
\text { Biomechanics }\end{array}$ & $\begin{array}{l}\text { Worked on the activation of innate immunity, the dendritic cell, } \\
\text { reprogrammed mature cells, regulation of vesicle traffic } \\
\text { machinery, a brain positioning system, a novel therapy against } \\
\text { roundworm parasites \& Malaria, mechanisms for autophagy, } \\
\text { molecular mechanisms controlling the circadian rhythm, cancer } \\
\text { therapy, and cells sense \& adapt to oxygen availability. }\end{array}$ \\
\hline
\end{tabular}

Source: Nobel Prize Organization (www.nobelprize.org)

The UK and Germany laureates in medicine have more awards before world war-II. Nevertheless, USA and UK laureates have dominated more in chemistry after world war-II. The laureates of medicine found new discoveries on the areas of physiology, immunology, biochemistry, epidemiology, hematology, patho physiology, microbiology, radiobiology, bioinformatics, biomechanics and molecular biology (Table 9). The study revealed that the discoveries of medicine assist in promoting health, wealth and prosperity by saving human lives all around the world.

Table 10: Decade Wise Nobel Prize Laureates Significant Contribution on Literature

\begin{tabular}{|c|c|c|c|}
\hline Year & $\begin{array}{l}\text { More } \\
\text { Awardees } \\
\text { from }\end{array}$ & Branch of Literature & Pioneering Contribution of Nobel Prize Laureates in Literature \\
\hline $\begin{array}{c}1901 \\
\text { to } \\
1910\end{array}$ & $\begin{array}{l}\text { Germany, } \\
\text { France, }\end{array}$ & Poetry, Non-fiction and Prose & $\begin{array}{l}\text { Evidence of lofty idealism, monumental work, history of nations, } \\
\text { inspiration, purity of spirit, natural scenery, deep learning, critical } \\
\text { research, virility of ideas, and idealistic philosophy of life. }\end{array}$ \\
\hline $\begin{array}{c}1911 \\
\text { to } \\
1920\end{array}$ & Denmark & $\begin{array}{l}\text { Poetry, Drama and non- } \\
\text { fiction }\end{array}$ & $\begin{array}{l}\text { Viewed on inspiration, literature of the West, descriptions of } \\
\text { present-day life, Olympian Spring, and Growth of the Soil. }\end{array}$ \\
\hline $\begin{array}{c}1921 \\
\text { to } \\
1930\end{array}$ & $\begin{array}{l}\text { Ireland and } \\
\text { France }\end{array}$ & Poetry, Drama and Fiction & $\begin{array}{l}\text { Viewed on human grace, sympathy, a true Gallic temperament, } \\
\text { traditions of the Spain, spirit of a whole nation, idealism, humanity, } \\
\text { rich \& vitalizing ideas, powerful descriptions of Northern life, } \\
\text { Budden brooks, and wit \& humor. }\end{array}$ \\
\hline $\begin{array}{c}1931 \\
\text { to } \\
1940\end{array}$ & USA & $\begin{array}{l}\text { Poetry, Drama and Non- } \\
\text { fiction }\end{array}$ & $\begin{array}{l}\text { Viewed on the Forsyte Saga, classical Russian traditions, concept of } \\
\text { tragedy, fundamental aspects of contemporary life as well as human } \\
\text { conflict, way of life, peasant life in China, and relationship with } \\
\text { Nature. }\end{array}$ \\
\hline $\begin{array}{c}1941 \\
\text { to } \\
1950\end{array}$ & UK & $\begin{array}{l}\text { Poetry, Fiction and Non- } \\
\text { fiction }\end{array}$ & $\begin{array}{l}\text { Expressed views on unique contribution to the modern America, } \\
\text { Latin American world idealistic aspirations, human problems \& } \\
\text { conditions with a fearless love of truth, and humanitarian ideals \& } \\
\text { freedom of thought. }\end{array}$ \\
\hline $\begin{array}{c}1951 \\
\text { to } \\
1960\end{array}$ & - & $\begin{array}{l}\text { Poetry, Narrative and Non- } \\
\text { fiction }\end{array}$ & $\begin{array}{l}\text { Expressed views on finding answers to the eternal questions } \\
\text { confronting mankind, human life, brilliant oratory in defending } \\
\text { exalted human values, demonstrated in The Old Man \& the Sea, } \\
\text { illuminates the problem of the human conscience, great Russian } \\
\text { epic tradition, the tragic experience of life, and human conditions } \\
\text { reflected by visionary fashion of our time. }\end{array}$ \\
\hline
\end{tabular}




\begin{tabular}{|c|c|c|c|}
\hline $\begin{array}{c}1961 \\
\text { to } \\
1970\end{array}$ & Russia & $\begin{array}{c}\text { Nonfiction, Fiction and } \\
\text { Narrative }\end{array}$ & $\begin{array}{l}\text { Expressed views on human destinies, social perception, Hellenic } \\
\text { world culture, spirit of freedom \& the quest for truth, Jewish people } \\
\text { motifs from the life, destiny of Israel with touching strength, the } \\
\text { essence of the Japanese mind, the destitution of modern man, and } \\
\text { Russian traditions. }\end{array}$ \\
\hline $\begin{array}{l}1971 \\
\text { to } \\
1980\end{array}$ & - & $\begin{array}{c}\text { Poetry, Non-fiction and } \\
\text { Narrative }\end{array}$ & $\begin{array}{l}\text { Expressed views on destiny, dreams, renewal of German literature, } \\
\text { the service of freedom, human values, human understanding \& } \\
\text { subtle analysis of contemporary culture, traditions, and severe } \\
\text { conflicts. }\end{array}$ \\
\hline $\begin{array}{c}1981 \\
\text { to } \\
1990\end{array}$ & - & Prose, Poetry and Drama & $\begin{array}{l}\text { Expressed views on continent's life and conflicts, human condition, } \\
\text { indomitable spirit \& versatility of man, the depiction of the human } \\
\text { condition, cultural perspective, clarity of thought, vulnerability, } \\
\text { intelligence, and humanistic integrity. }\end{array}$ \\
\hline $\begin{array}{l}1991 \\
\text { to } \\
2000\end{array}$ & Poland & $\begin{array}{l}\text { Poetry, Fiction and Non- } \\
\text { fiction }\end{array}$ & $\begin{array}{l}\text { Expressed views on humanity, multi-cultural commitment, reality, } \\
\text { life, myth, everyday miracles \& the living past, dignity, forgotten } \\
\text { face of history \& bitter insights and linguistic ingenuity. }\end{array}$ \\
\hline $\begin{array}{l}2001 \\
\text { to } \\
2010\end{array}$ & UK & Fiction and Non-fiction & $\begin{array}{l}\text { Expressed views on suppressed histories, the individual experience } \\
\text { against the barbaric arbitrariness of history, involvement of the } \\
\text { outsider, the absurdity of society's clichés, everyday forces \& } \\
\text { prattle entry into oppression's closed rooms, civilization, clash \& } \\
\text { interlacing of cultures, humanity, and dispossessed landscape, } \\
\text { resistance, revolt, and defeat of the individuals . }\end{array}$ \\
\hline $\begin{array}{l}2011 \\
\text { to } \\
2019\end{array}$ & - & Fiction and Narrative & $\begin{array}{l}\text { Expressed views on access to reality, ungraspable human destinies, } \\
\text { suffering, courage, tradition, sense of connection with the world, } \\
\text { crossing of boundaries, and the specificity of human experience. }\end{array}$ \\
\hline
\end{tabular}

Source: Nobel Prize Organization (www.nobelprize.org)

The contribution of laureates in literature found to be more in France during 1901 to 2019. The experts of literature exposed their ideas through poetry, prose, non-fiction, narrative, fiction and drama (Table 10).

The study found that the views of literature laureates expressed their experiences regarding the man how to human act throughout ones' own life. The feelings of literature laureates help to know how human culture, tradition, values, behavior, reality, tragedy, truth, love, inspiration, and act changes along with time and situations in the world.

\section{Significant Contribution of Noble Prize Laureates on Peace:}

Nobel Prize laureates on peace awarded for their efforts on democracy, pioneering humanitarian work, social justice, ethno-cultural reconciliation, solving of international conflicts, peace, non- violence, international cooperation, man-made climate change, sustainable development, international cooperation, prohibition of nuclear and chemical weapons, human rights and socio- economic development during the period of 1901 to 2019 . International organizations received more Nobel prizes in Peace. The study found that laureates who won Nobel Prize in peace contributed their work mostly on democracy, international cooperation, international conflicts and elimination of nuclear weapons. The peace promotes true happiness in the human life.

Table 11: Decade Wise Nobel Prize Laureates Significant Contributions on Economic Sciences

\begin{tabular}{|c|c|c|c|}
\hline Year & $\begin{array}{c}\text { More } \\
\text { Awardees } \\
\text { from }\end{array}$ & Branch of Economics & Pioneering Contribution of Nobel Prize Laureates in Economic \\
Sciences
\end{tabular}




\begin{tabular}{|c|c|c|c|}
\hline $\begin{array}{c}1971 \text { to } \\
1980\end{array}$ & $\begin{array}{l}\text { USA and } \\
\text { Russia }\end{array}$ & $\begin{array}{l}\text { Micro and } \\
\text { macroeconomics, } \\
\text { Econometrics and } \\
\text { International Trade }\end{array}$ & $\begin{array}{l}\text { Interpretation of economic growth, general economic theory of } \\
\text { equilibrium and welfare, input-output method, money and economic } \\
\text { fluctuations theory, optimum allocation of resources theory, } \\
\text { consumption analysis, monetary history, theory of international trade } \\
\text { decision-making process, economic development and econometric } \\
\text { models. }\end{array}$ \\
\hline $\begin{array}{c}1981 \text { to } \\
1990\end{array}$ & USA \& France & $\begin{array}{c}\text { Public Finance, } \\
\text { Macroeconomics and } \\
\text { Development Economics }\end{array}$ & $\begin{array}{l}\text { Analysis of financial markets, industrial structures, functioning of } \\
\text { markets, reformulation of the theory of general equilibrium, systems of } \\
\text { national accounts development, saving \& of financial markets } \\
\text { economic and political decision-making theory, theory of economic } \\
\text { growth, markets and efficient utilization of resources theory, } \\
\text { foundations of econometrics, and theory of financial economics. }\end{array}$ \\
\hline $\begin{array}{c}1991 \text { to } \\
2000\end{array}$ & USA \& Canada & Economic Theory & $\begin{array}{l}\text { Significance of transaction costs, microeconomic analysis, analysis c } \\
\text { equilibria, hypothesis of rational expectations, economic theory c } \\
\text { incentives, the value of derivatives, welfare economics, monetary an } \\
\text { fiscal policy, methods and theory for analysis of selective samples an } \\
\text { theory and methods for analyzing discrete choice. }\end{array}$ \\
\hline $\begin{array}{c}2001 \text { to } \\
2010\end{array}$ & USA & Economic Theory & $\begin{array}{l}\text { Analyses of markets with asymmetric information, psychologica } \\
\text { research into economic science, established laboratory experiments } \\
\text { empirical economic analysis, time- varying volatility, common trends } \\
\text { dynamic macroeconomics, understanding of conflict and cooperation, } \\
\text { Governance of economies especially the commons, the firn } \\
\text { boundaries, trade patterns, analysis of inter-temporal trade-offs an } \\
\text { foundations of mechanism design theory. }\end{array}$ \\
\hline $\begin{array}{c}2011 \text { to } \\
2019\end{array}$ & USA \& France & $\begin{array}{l}\text { Development Economics } \\
\text { and Behavioral } \\
\text { Economics }\end{array}$ & $\begin{array}{l}\text { Cause and effect in the macro economy, stable allocations theory a } \\
\text { the market design practice, analysis of asset prices, market power a } \\
\text { regulation, consumption analysis, poverty, welfare, integrati } \\
\text { innovative technologies into long-run macroeconomic analys } \\
\text { contract theory, behavioral economics, and alleviating global poverty }\end{array}$ \\
\hline
\end{tabular}

Source: Nobel Prize Organization (www.nobelprize.org)

The noble prize laureates who awarded in economic sciences contributed work on different areas of economics such as economic theory, macroeconomics, international trade, public finance, development economics and behavioral economics. USA laureates are more dominant in getting Nobel Prize of economic sciences (Table 11). The study found that the inventions and technology of economics mainly help to boost an economy of the nations and growth of the new business across the world.

\section{Summary:}

Over the years, we are gradually losing a set of morals, mainly humanistic ones for which the Nobel Prizes are one of our last bastions. Creative minds contributed to the development of universe and humanity. The present paper shares, percentages and analyses global, continental, country wise Nobel Prize laureate's inventions, theories, evidences, insights, knowledge, ideas and rationales of great persons that would help to galaxy of future inventors. The results showed that out of 213,106 USA, 25 UK, 18 Germany and 15 France laureates awarded in physics, which was accounted to be $49.77,11.74,8.45$ and 7.04 per cent, respectively.

Out of 184 laureates, 82 USA (44.57\%), 30 Germany (16.30\%), 29 UK (15.76\%) and 9 France (4.89\%) laureates awarded Nobel Prize in chemistry. Out of 219 laureates, 113 USA, 30 UK, 15 Germany and 11 France laureates got Nobel Prize in physiology or medicine, which accounted to 51.60, 13.70, 6.85 and 5.02 per cent. Noble Prize awarded more in physics, chemistry and medicine to USA laureates followed by UK, Germany and France. USA is healthy historic investment in basic science, academic freedom for researchers, and placidity to see outcomes. The USA owes ample to its impressive lead in research scientifically, including prosperity, advancement of technology and security. US is helpful to uphold its deep grip of science, lavish government support in the form of research grants practically open borders that mark it viable to generate in the best minds of world. A per-capita analysis of physics, chemistry and medicine laureates since the turn of the century reveals that the UK as the most prolific nation. UK entities have all been identified for stupendous contributions in pioneering medical research. Out of 116 laureates, 17 France, 12 USA, 11 UK laureates awarded Nobel Prize in literature, which accounted to be 14.66, 10.34 and 9.48 per cent, respectively. German scientists have the pro of a cultured education system. France population has a relatively high IQ compared to USA, UK and Germany in literature. Out of 107 laureates, 23 USA, 11 UK and 9 France laureates awarded Nobel Prize in peace, which accounted to be 21.50, 10.28 and 8.41 
per cent, respectively. Other than four nations has dominant in Noble prize of peace followed by UK and France. The study found that USA has solo Nobel Prize winner in economic sciences since laureates have introduced new approaches to acquire reliable answers to fight with present day existing problems, which further help in improving the lives of the worst-off people around the world. The contribution of physics in France and Germany realized to be more before world war-II. However, the same was more in USA after world war-II. Nobel Prizes are USA and Euro Centric not global centric. This is due to USA and Europe policies are encouraging more creative minds and invest more on Human intellectual capability. There are criticisms about political bias, illegal contracts for fame and strongest economy. Most of the foreign intellectuals other than USA, work for USA, as their own countries were not encouraged innovative thoughts of intellectuals and no grants from the government of those countries especially in research areas. The physics inventions are highly useful for the future progress of people and generate an essential knowledge required for the technological advances in future, which leads to initiative the economic growth of the universe. The chemistry inventions assist to solve many future problems such as controlling our environmental conditions, providing safe drinking water facilities, food production, and promoting human wellbeing. The medicine inventions assist in promoting health, wealth and prosperity by saving human lives all around the world. The feelings of laureates in literature help to know how human culture, tradition, values, behavior, reality, tragedy, truth, love, inspiration, and act changes along with time and situations in the world. The peace promotes true happiness in the human life. Economics inventions and technology mainly help to boost an economy of the nation and growth of the new business across the world.

Suggestions:

The researchers of USA, UK, Germany and France get more Nobel prizes in all categories when compared to other nations. This shows that Nobel prizes awards are more Europe and USA centric not global centric. This may be due to they are more creative minds, scientific advancements and economic developments but they are criticisms about lobbying or procedural bias. The Royal Swedish academy and UNO-UNESCO have to bring awareness programs, in selection procedures in Asia, Africa, Latin American countries. Nobel Prize of peace and literature awarded to these continents. Not all inventions and discoveries of Nobel laureates may be helpful to humankind. Highly populated countries such as China and India become insular. They are not more in the list of Nobel Prize winners. It means no grants from government to expose the great intellectuals' knowledge and ideas to outside world. So many subjects such as psychology, philosophy and mathematics are neglected while selecting winners even though those disciplines are helpful to humankind either directly or indirectly. It means the greatest contributions other than six disciplines are not considerable by the Nobel Selection Committee. Nobel Prize selection committee must select those inventions, which helps truly to the humankind without considering the disciplines.

\section{References}

García-Bellido, J. Why are Nobel Prizes important? Lindau Nobel laureates Meeting. https://www.lindaunobel.org/why-are-nobel-prizes-important/ posted on 6-27(2012).

Lieff Benderly, B. How to win a Nobel Prize. American Association for the Advancement of Science. doi:10.1126/science.caredit.a1500240 10-12(2015)

Brian Keating. Should all Nobel Prizes be cancelled for a year? COSMOS, the Science of Everything 9-23(2018). Nobel Prize Organization (1990).

The Nobel Prize Awarding Great Minds, Sweden Sverige. https://sweden.se/society/the-nobel-prize-awardinggreat-minds/ 28-11(2018).

Susannah Locke. How the Nobel Prize became the most controversial award on Earth Vox. News. www.chemistryworld.com5-10 (2016).

Philip Ball. Are the Nobel Prizes good for Science? Chemistry World 1-10 (2018).

Stephan, P.E. \& Levin, S.G. Age and the Nobel Prize revisited. Scientometrics. https://doi.org/10.1007/BF0202651728, 387-399 (1993).

Nobel Prize facts. NobelPrize.org. https://www.nobelprize.org/prizes/facts/nobel-prize-facts26- 02 (2020).

Ed Young. The Absurdity of the Nobel Prizes in Science. The Atlantic, https://www.theatlantic.com/science/archive/2017/10/the-absurdity-of-the-nobel-prizes-in science/541863/3-10 (2017).

Francesca Rita Novara, Jan Bäckvall \& Ken Houk. The Importance of Nobel Prizes for Today's Research Chemistry. ChemViews Magazine of ChemPubSoc. DOI: 10.1002/chemv.201800017 08-03(2018)

Smriti, M. UK challenges US in Nobel dominance. Nature Index 09-05 (2018).

Jason Socrates, B. Why Do So Many Americans Win the Nobel Prize? Inside Science, American Institute of Physics (2019).

Jon Bruner. American Leadership in Science, Measured in Nobel Prizes [Infographic].Forbes bi-weekly magazine 05-10(2011).

Neil Withers, Philip Robinson, Ben Valsler, Patrick Walter. The data behind the Nobel prizes. Royal Society of Chemistry 07-10 (2019). 